\title{
Sustainable Development of Poverty Impacts in Industrial Region with Local Competency Approach in Central Java Province
}

\section{Luis Antero Da Costa and Prawoto Sarpoyo Susilo Parmansyah}

Universitas Diponegoro

\section{Abstract}

The poverty of industrial areas is interesting to be studied because the industrial area should be a potential that will bring benefits to the region concerned. However, in reality, many industrial areas with poor community conditions. The problem of sustainability of poverty alleviation efforts that have been done so far is dependent on the availability of the budget and depends on the government's commitment as the

Corresponding Author: Luis Antero Da Costa luis.antero.costa@gmail.com

Received: 7 August 2018 Accepted: 15 September 2018 Published: 22 October 2018

Publishing services provided by Knowledge $\mathrm{E}$

(c) Luis Antero Da Costa and Prawoto Sarpoyo Susilo

Parmansyah. This article is distributed under the terms of the Creative Commons

Attribution License, which permits unrestricted use and redistribution provided that the original author and source are credited.

Selection and Peer-review under the responsibility of the ICE-BEES 2018 Conference Committee.

\section{G OPEN ACCESS} implementer of poverty eradication program. This happens because there are many factors that cause less optimal contribution of local competence in poverty alleviation efforts in Central Java Province. In its existence, local competencies that grow and develop in society can not be separated from aspects of geographical, historical, and socio-political conditions. The number and condition of poverty in industrial areas can not be separated from the rate of industrialization that is not based on the empowerment of local residents and the lack of attention of stakeholders to local competence in the community. This research uses descriptive research type with qualitatif approach.

Keywords: Poverty, Local Competence, Industrial Area, Region Potential and Central Java

\section{Introduction}

Without synergism among various development actors, development programs would be failed [16]. Bryson, Crosby, \& Stone (2006) explained that people want to tackle difficult social problems, have begun to realize that various development components are engaged in business, nonprofit, or philanthropy; must synergize together to face challenges and achieve effective results. Under these circumstances, more and more leaders are found in government organizations that facilitate and operate at multiorganizational level in order to network and solve arrangements. problems that are interrelated and can not be solved easily by a single sector [18]. 
In realizing the development of society's prosperity through economic development to overcome various social and development problems such as unemployment and poverty. In addition to economic growth, one important aspect of looking at development performance is how effective the use of existing resources so that employment can absorb the available labor force. Increasing economic growth means the production of goods / services produced increases. Thus more labor is needed to produce the goods / services so that unemployment is reduced and poverty is decreasing [22].

Industrial area is one of the efforts of the Indonesian government in developing industrialization in Indonesia. Act of Republic of Indonesia number 5 year 1984 about the industry, explained that the government can set central areas of industrial growth and location for industrial development in accordance with its purpose in the realization of the insight of the archipelago. People who are in one location with the industry will certainly generate an interaction. Such interaction can give rise to a variety of gaps in both economic and educational matters. The gap can also lead to new social conflicts and structures. This situation is increasingly in-depth emerging target of the development activities of an industrial estate is a large entrepreneur and foreign investors, not intended for local communities living in the surrounding areas [1].

Central Java Province is one of 35 (thirty five) provinces in Indonesia that also experience poverty problems. Central Java province currently has 35 (thirty five) regencies and cities which certainly has a wide range of problems that must be immediately. In the period of 5 (five) years ie from 2011 to 2015 there is a decrease in poverty in all regencies / cities in the Province of Central Java. In 2011, the first rank experienced a poverty rate of 5,256 (million inhabitants) 16.21 (presen), then in 2012 to $20144,561.82$ (million people) 13.58 (percent), but the poverty rate increased by 2015 by 4.577 .038 (million souls) 13.58 (presen).

Economic growth is an economic indicator that can show a picture of the success of an economic development. Economic growth is an indicator to see the success of development and is a necessary condition for reducing poverty. The requirement of sufficiency is that economic growth is effective in reducing poverty. That is, the growth should spread in every income class, including in the poor. Directly, this means that growth will need to be ensured in sectors where the working poor are the agricultural sector or the labor-intensive sectors. Indirectly, it is necessary for the government to effectively distribute the growth benefits that may come from the modern sector such as capital-intensive services (Hermanto Siregar and Dwi Wahyuniarti, 2008). For more details can be shown in Figure 1 below

Based on the graph.1 shows that until 2016 the rate of economic growth in Central Java Province decreased from 20125.34 percent decreased to 5.11 percent in 2013 and increased by 5.27 in 2014 and increased by 5.47 percent in the year 2015 and fell back 


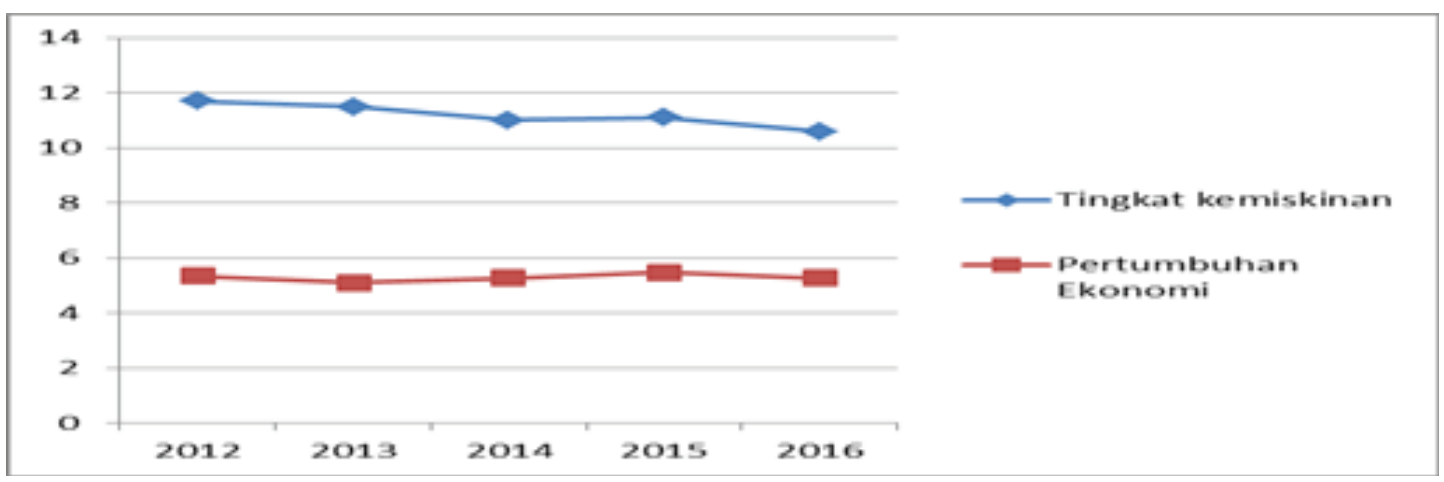

Figure 1: Economic Growth and Poverty in Central Java Year 2012-2016 (percent). Source: BPS Indonesia.

5.28 percent in 2016. The increase and the rate of economic growth is followed by the tendency of decline of the poor from year to year. which is 11.7 percent in 2012 and fell to 11.5 percent in 2013 and dropped to 11.0 in 2014 and increased again 11.1 percent in 2015 but fell back to 10.6 in 2016.

Changes in strategic environments such as economic globalization and regional autonomy demand changes in the way institutional institutions operate, including institutional poverty alleviation at the local level. Poverty is a development issue in many areas characterized by unemployment, underdevelopment and deterioration. Poverty can hinder the achievement of democracy, unity, and justice, so poverty reduction is needed in order to strengthen the foundation of sustainable economic development.

According to Mankiw (2008) that development of human resources can be done with the improvement of the quality of human capital. Human capital can be seen from a quality education and a healthy society. Education and health is one of the most important factors of poverty. Health is at the core of prosperity, while education is essential to achieving a decent life ([21]: 28).

Resolving problems that can not be postponed, it should be a top priority in the implementation of development in accordance with the principle of justice in realizing the economic system populist; and also a national commitment that must be done systematically, across sectors, across perpetrators, integrated, and sustainably. In the effort of poverty reduction, the government has limitations not only in terms of organization or technical management, but also operational, as well as finance or funding. Through KEPPRES no. 124 of 2001 jo no. 8 In 2002 the government established the Poverty Reduction Committee (KPK) which specifically organizes poverty alleviation efforts in Indonesia by involving all stakeholders at all levels.

A number of variables can be used to assess poverty, as well as in the context of poverty in industrial areas. Various poverty variables such as education, health, economy, culture, and structure are expected to produce poverty reduction strategies 
and policies that are expected to be targeted and sustainable. In general, education and poor quality of health are seen as the cause of poverty. Particularly in the industrialized community, the ownership of limited production tools and technological mastery is underestimated as the cause of sluggishness in the production process, which makes the society less able to compete with other industry actors and ultimately perpetuate poverty. Similarly, culture and structural factors are also often seen as an important element that determines the level of community welfare

The existence of local competence in the community as a potential that can be used even optimized in poverty reduction efforts will always be faced with two things, namely as something that will be associated with a context acceptable to a socioprofessional or market entity, so that it can be referred to as size of skill level in the field. On the other hand there is the pull of complex (cultural) substances, as a multisectoral, multidimensional, and dynamic link.

Accordingly, regional development undertaken by the government and other stakeholders should be based on local resources and competencies owned by the region concerned. Unfortunately in Central Java this era of regional autonomy, it can not be realized, because the development is still uniform or based on the program that style and the variety impressed each other imitations or imitations. Ideally, the resources and potential possessed by a region must be aligned in its optimization with the development program, that is through the development of local competencies in the midst of society through the process of interaction and social learning process in the community.

\section{Literature}

\subsection{Literature review}

\subsubsection{Theory of synergism}

The theory of synergism between entities or components will give a better sense of results. Synergism in the context of economic management is basically the collaboration or cooperation of two or more components that are committed and forming a system of mutual influence to achieve common goals and provide a better or different change of their respective effects (synthesized from the opinion of Richard, 2007; Corning, 1998, Anderson \& Carter, 1974; Andrushko, 2012; Corbin, Mittelmark, and Lie, 2011; Lasker, Weiss, and Miller, 2001; Carnwell and Carson 2005). As already noted above that various poverty reduction programs have been implemented by the Government but the results are not yet optimal. According to Midgley (1995, 
pp. 3-4) poverty is one of the consequences of distorted development, which is the phenomenon of economic development that is not aligned with social development, because it is too pursuit of growth so that the results can not be enjoyed by a group that is less competitive and left behind. As a result, economic development tends to produce "twin outputs" that is growth and poverty Nugroho, Adam, Tjitroresmi, and Aryo (2010). Therefore, there must be a development concept that prevents the widening of the welfare gap process as a result of economic development which is growth-oriented.

\subsubsection{Poverty theory}

Actually there is no definition and standard size in determining poverty. Between the US and the EU there is a difference in the concept of poverty level. America defines the concept of poverty as a lack of income to meet basic needs. While the EU defines poverty as social disadvantage. Ironically it is an Englishman named B. Seebohm Rowntree who pioneered the American method of determining the poor by estimating a revenue threshold (monetary absolute) based on the provisions in making a living.

Nevertheless the European Union has always refined the concept of poverty by adopting a view of poverty relative to the rising standard of living on average, and most recently the concept of poverty is a framework or concept to think about disadvantages not only from the monetary aspect but also from the aspect non-monetary aspect. Therefore the EU has a commitment to include those who are left behind or those who are out of the mainstream and left behind in a global economy into a development process. According to an economist (Mollie Orshansky, 1964) argues that to determine the poverty line must be according to the rules. It has since been the subject of discussion in policy meetings and social science. Based on the value of a "food economy plan" that has been done three times (where every family spends only one-third of the income they earn after taxes). John Kenneth Galbrait points out that the determination of the threshold or poverty line is adjusted to inflation, this is done to know the material state of people who are under the degrees and standards of society. In 1995 the National Academy of Sciences recommended limited changes to the poverty line to reflect real consumption relative to all money and non-monetary resources, minus occupational expenditures. In contrast, the EU adopted the official poverty line as a relatively poverty indicator of half of the median national household income that could be spent. This increases as Europe grows richer. 


\subsubsection{Local competency}

Speaking of the concept of competence, especially local competence, references related to the definition of competence are

1. A competency refer to an individual's demonstrated knowledge, skills or abilities (KSA's) performe to a specific standard. Competencies are observable, behavioral acts that requare a combinataion of KSAs to execute. They are demonstrated in a job context an as such, are influenced by an organization's culture and work environment. In other words, competencies consist of a combination of knowledge, skill, and abilities that are necessary in order to perform a major task of function in the work setting (JGN Consulting, Denver, USA).

2. Competency comprises knowledge and skills and the consistent application o that knowledge and skills to the standard of performance required in employment (Competency Standart Body, Canberra 1994).

3. Competency models that identify the skills, knowledge, and characteristics needed to perform a job (A.D. Lucia \& R. Lepsinger/Preface xiii).

From the above definitions can be formulated that the competence is defined as the ability of a person who can be observed include the knowledge, skills and attitudes in completing a job or task in accordance with the standard performance (ability of work) is defined and the uniqueness of a particular area.

\subsubsection{Research framework}

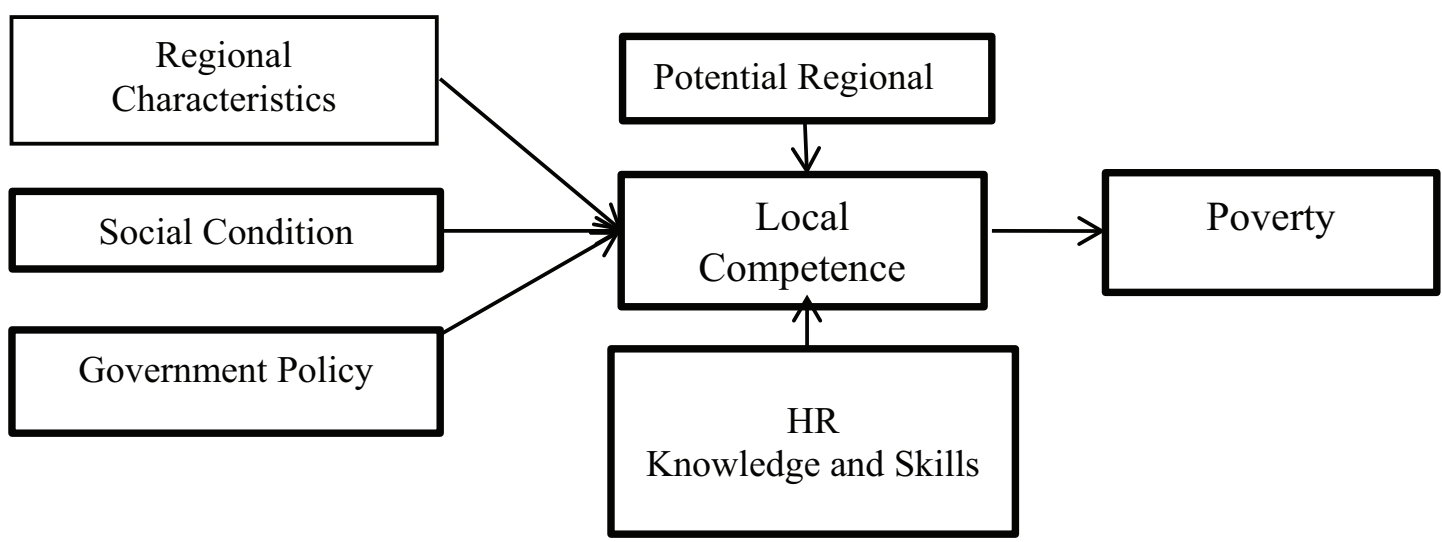

From the chart above, it appears that the characteristics of the region, social conditions, government policies, forming local competencies that can be used to cultivate the potential of the region so as to generate income (income generating). This process should build community productivity. But there are external factors in the form of government policy, capital penetration, and globalization that hamper the development of 
community productivity resulting in structural poverty. Meanwhile, on the other hand, in the local competence transfers and the development of knowledge and skills so as to build a work ethic. Under these conditions, poverty must be reduced and local competencies must be optimized so that poverty can be overcome

\subsubsection{Model}

This local economic development research is carried out with qualitative approach with explanatory research type. Bryman (2008, p.373) states that generally qualitative research is inductive, but some researchers conduct qualitative research to test theories, so that in qualitative research it is possible to be deductive and there is no reason why qualitative research can not be used to test the theories specified before data collection. This is similar to the opinion of Batektine (2008), Silverman (2011), Creswell (2009). According to Creswell (2009 p. 93-98) there are four types of qualitative research according to the role of theory in it, namely: (1) using theory as a hypothesis; (2) using theory as a general guide for research (3) using theory as the final point of the study and applying the research process inductively, and (4) not explicitly using the theory.

\section{Discussion}

\subsection{Local competence in tackling poverty in industrial areas}

Poverty is a complex issue. Therefore, the way to overcome it requires proper analysis, involving all components including the poor itself and the need for an appropriate, sustainable, and non-temporary handling strategy. However, when examined, poverty alleviation efforts carried out during this time, among others through the provision of basic needs such as food, health and education services, expansion of employment opportunities, grants through the credit system, and infrastructure development, still material oriented and has not touched the aspect of atitude or attitude of the poor. Even the various programs that have not optimally involve and develop the potential and capacity that already exist and owned by the poor themselves.

Local competencies are at least built on the knowledge, attitude, and skills of individuals in a society to do something. These competencies are built together through various dynamics. Historically, there was a tradition of community inheritance by socialization agents to individual members of society. In this process there is inheritance of competence to new generations in society. The inherited competence is then subjected to objectivization so that it becomes a common property. When that happens, what 
is inherited finds various realities that require it to change or even be abandoned. The local competencies of the people of Central Java province should be a strong capital for the efforts to build a prosperous life. But in fact, poverty rate in central java province is still high. This happens because there are many factors that cause less optimal contribution of local competence for poverty alleviation efforts in Central Java province.

Local competencies are at least built on the knowledge, attitude, and skills of individuals in a society to do something. These competencies are built together through various dynamics. Historically, there was a tradition of community inheritance by socialization agents to individual members of society. In this process there is inheritance of competence to new generations in society. The inherited competence is then subjected to objectivization so that it becomes a common property. When that happens, what is inherited finds various realities that require it to change or even be abandoned. Thus, the formulation of local competence can not be separated from the two sides of the study. One side when speaking of local competence is related to a context acceptable to a social or professional entity or "market", so that it can be referred to as a measure of the level of expertise in the field. On the other hand there is the pull of complex (cultural) substances, as a multisectoral, multidimensional, and dynamic link. "Agreement" can only be achieved through a compromise between the two sides, not by arbitrary adoption to defeat or win one pole from the other. If the competence formula won the first (standard), then it will be separated from the substance,

\section{Conclusions}

Each community has its own competence so that the uniqueness appears in accordance with the locality of the community is located, which naturally local competence grows and develops in line with the efforts to meet the needs of people's lives and can not also be released from social changes that occur in society. Local communityowned competencies are formed, grown and developed along with the growth and development of geographic, historical and socio-political conditions of the region so that the government as a policy holder and as an element of development planner plays an important role in the development of local competence of a region as well as local competence can contribute positively to poverty reduction efforts.

\section{References}

[1] Ajipadma Kusumaningtyas., (2006) kemiskinan masyarakat disekitar kawasan industry JABABEKA (studi kasus desa gombong kecamatan cikarang utra kab 
bekasi. Institute pertanian bogor.

[2] Anderson, Ralph E. \& Carter Irl.E. (1974). Human behavior in social environment. A social systems approach. Chicago: Aldin Publishing Company.

[3] Bahua, Mohamad Ikbal. 2008. Pemberdayaan dalam Makna Kemiskinan. Bahua Ikbal Kreatif Blogspot.

[4] Batektine, Alex. (2008). Prospective case study design qualitative method for deductive theory testing. Organizational Research Methods. Volume 11 (1) January 2008. P. 160-180. Sage Public Publication.

[5] Bryman, Alan. (2008). Social research methods. Third edition. Newyork: Oxford

[6] Bryson, John M; Barbara C Crosby; and Melissa Middleton Stone. (2006). The design and implementation of cross-sector collaborations: propositions from the literature. Jurnal Public Administration Review. Spesial issue edition, Desember 2006. p 44-55.

[7] Chaniago, Andrinof A. Kompetisi, Kompetensi dan Pembangunan Daerah. Suara Pembaruan, 26 November 2002.

[8] Corning, Peter A. (1998).the synergism hypothesis. On the concept of synergy and it's role in the evolution of complex systems. Journal of Social And Evolutionary Systems, Vol 21 No 2

[9] Creswell, John W. (2009). Research design. Pendekatan kualitatif, kuantitatif, dan mixed. Edisi Ketiga. Terjemah Ahmad Fawaid. Yogyakarta: Pustaka Pelajar.

[10] Erickson, Thomas and Wendy A. Kellogg. 2000. "Social Translucence: an Approach to Designing Systems that Support Social Process" in ACM Transaction on ComputerHuman Interaction, Vol 7, No.1.

[11] Glen, Andrew. 1993. "Methods and Themes in Community Practice" in Butcher, H., et.all (eds)., Community and Public Policy, London: Pluto.

[12] Lasker, R.D., Eliza S. Weiss, \& Rabecca Miller. (2001). Partnership synergy: a practical framework for studying and strengthening the collaborative practice and research." Malden: Blackwell Publisher.

[13] Mankiw,N Greogory. 2008. Makroekonomi Edisi Ketujuh. Jakarta: Erlangga.

[14] Manning, Chris dan Tajudin Tukiran. 1990. Struktur Pekerjaan Sektor Informal dan Kemiskinan di Kota (Sebuah Sudi Kasus di Diroprajan Yogyakarta). Yogyakarta: UGM Press.

[15] Midgley, James. (1995). Social development. The development perspective in social welfare. London: Sage Publication.

[16] Nemes, Gusztáv. (2005). Integrated rural development: the concept and its operation. Budapest: Institute of Economics Hungarian Academy of Sciences. 
[17] Nugroho, Agus Eko, Latif Adam, Endang Tjitroresmi, dan Bagus Aryo. (2010). Analisis permasalahan kemiskinan. Dalam buku program anti kemiskinan reproduksi modal sosial, studi kasus PNPM Mandiri Perdesaan. Agus Eko Nugroho (Ed). Jakarta: LIPI Press.

[18] O'Leary, R., Gazley, B. McGuire M, \& Bingham L.B (2009). Blomgreen. Public Managers in Collaboration. In The Collaboratiotive Public Manager: New Ideas For The Twenty -First Century.(O'Leary R. Bingham,L.B ed) Washiongton, D.C. Georgetown: University. Press. In Zhang Nan and Lu Zhikui.

[19] Silverman, David. (2011). Interpreting qualitative data: methods for analysing qualitative data. London: Sage. p. 448.

[20] Suharto, Edi. 2005. Membangun Masyarakat Memberdayakan Rakyat. Bandung: Refika Aditama.

[21] Todaro, Michael, P. Dan Stephen C. Smith, 2006, Pembangunan Ekonomi. Edisi Kesembilan, Jakarta: Erlangga.

[22] Yacoub, Yarlina. 2012. "Pengaruh Tingkat Pengangguran Terhadap Tingkat Kemiskinan Kabupaten/Kota di Provinsi Kalimantan Barat.". Jurnal EKSOS. Vol.8, No.3, Hal.176-185. Oktober. 